\title{
Into the woods: Partnering with the Department of Corrections to deliver forestry extension programming
}

\author{
by Jason S. Gordon ${ }^{1, *}$, Scott Cagle ${ }^{2}$, John D. Kushla ${ }^{3}$ and Brand Huffman ${ }^{4}$
}

\begin{abstract}
This paper describes a pilot series of extension programs delivered to inmates within the Mississippi Department of Corrections system. The project was a collaboration between the Chickasaw County Regional Correctional Facility, state Extension forestry specialists, and county Extension staff. A large body of research describes benefits of inmate education, including lower recidivism and reducing tension that could otherwise lead to behavioral problems. Over four months, Mississippi State University Extension personnel worked with prison officials to educate inmates about forestry, logging, and arboriculture. This paper describes the collaborative process driving the project as well as program design, curriculum, materials, and delivery. Besides technical information, instructors discussed opportunities and challenges inmates may encounter if they were to pursue employment in forestry or tree care following their sentences. Instructors worked closely with prison staff to appropriately address teaching in a unique environment and the educational needs of the students. We present the student evaluation process, which was limited by prison rules. Finally, we present results from an evaluation of partners and instructors that elaborate on pitfalls, challenges, and opportunities. The Department of Corrections was highly satisfied with the program and has requested expansion to facilities across the state.
\end{abstract}

Keywords: forestry extension, prison training, U.S. South, arboriculture, vocational skills, special needs

\section{RÉSUMÉ}

Cet article décrit une série de programmes pilotes de formation donnée à des détenus du Département des services correctionnels du Mississipi. Le projet est né de la collaboration entre létablissement pénitentiaire régional du comté de Chickasaw, les spécialistes en formation forestière de l'État et le personnel responsable du transfert technologique pour le comté. De nombreuses recherches démontrent les avantages de former les détenus, notamment un niveau plus faible de récidive et une réduction de la tension qui pourrait autrement engendrer des problèmes de comportement. Pendant quatre mois, le personnel du service de consultation de l'Université de l'État du Mississipi a travaillé avec le personnel de la prison pour enseigner aux détenus la foresterie, lexploitation forestière et l'arboriculture. Cet article décrit le processus collaboratif, la base de ce projet, ainsi que la structure du programme, son contenu, le matériel pédagogique et les méthodes de prestation. En plus du contenu technique, les instructeurs ont analysé les possibilités et les défis que les détenus pourraient rencontrer s'ils voulaient poursuivre une carrière en foresterie ou en arboriculture une fois libérés. Les instructeurs ont travaillé étroitement avec le personnel de la prison afin de pouvoir adapter leur enseignement à un environnement aussi spécial et en fonction des besoins éducatifs des étudiants. Nous présentons le processus dévaluation des étudiants qui a forcément été limité par les règlements de la prison. Finalement, nous présentons les résultats de lévaluation qu'en ont faite les partenaires et les instructeurs et qui mentionne les écueils, les défis et les possibilités. Le Département des services correctionnels sest montré très satisfait du programme et a demandé quoon le rende disponible aux autres établissements de l'État.

Mots clés : service de formation forestière, formation en milieu carcéral, sud des États-Unis, arboriculture, compétences professionnelles, besoins spécifiques

\footnotetext{
${ }^{1}$ Department of Forestry, Mississippi State University, Mississippi State, MS 39762; * corresponding author: jg966@msstate.edu

${ }^{2}$ Mississippi State University Extension Service, Houston, MS 38851

${ }^{3}$ Extension Professor, Department of Forestry, Mississippi State University, Verona, MS 38879

${ }^{4}$ Warden, Chickasaw County Regional Correctional Facility, Jackson, MS 38851
} 


\section{Introduction}

The United States correctional system is an acute societal issue. The nation has consistently experienced the largest incarceration rates in the world with the prison population nearly tripling between 1980 and 2014 (Bureau of Justice Statistics 2015, World Prison Brief 2016). Further, recidivism is a common problem while correction facilities and programs, including probation and parole, cost tax payers around $\$ 74$ billion in 2007 (Kyckelhahn 2011, Davis et al. 2013). The growth and costs of the prison population have focused attention on the educational characteristics of the prisoners. Adult inmates have lower levels of educational attainment than the general population with over $40 \%$ of incarcerated individuals not completing high school (Harlow 2003). Besides lower levels of educational attainment, prisoners often lack vocational skills and a consistent history of employment (Davis et al. 2013).

Prison education programs seek to address this problem by developing skills for post-prison workplaces (Davis et al. 2013). Such programs have been shown to reduce recidivism, have a calming effect on the prison community, and improve job outlook upon release (Coley and Barton 2006). Ewert and Wildhagen (2011) suggest prison education programs may reduce recidivism rates by changing behavior through improved cognitive skills and socialization towards society norms that reject criminal behavior. Moreover, education programs have reduced incarceration costs by four to five dollars during the first three years post-release for each dollar investment in prison education (Davis et al. 2013). In addition to literacy, General Education Development (GED), and college courses, a common vocational program topic is horticulture, with gardening programs having been practiced in U.S. prisons since the 1800s and Cooperative Extension leading the effort in several states (e.g., Reld and Dorn 1995, Robinson and O'Callaghan 2008). Less common are programs covering forestry and arboriculture topics.

This article describes a forestry extension education program to low-risk male inmates in the Mississippi correctional system. The project highlights collaboration between Extension and the Chickasaw County Regional Correctional Facility (RCF). The overall goal of the project was to create awareness among inmates regarding various forest management and urban tree care topics. Specific learning objectives included participants: (1) gaining awareness about potential employment opportunities; and, (2) broadening their knowledge base. Additional project objectives were to: (1) cultivate a partnership between Extension and the Mississippi Department of Corrections; (2) test a forestry educational model for a correctional facility audience; and, (3) provide a distraction from the daily stresses and challenges of prison life. We provide this article with the hope that Extension professions will consider prison inmates as a potential non-traditional audience for natural resources outreach education.

\section{Procedures}

Institutional collaboration was essential to the success of the project. The project was initiated by the County Extension Agent and the Correctional Facility Warden. The Warden suggested forestry and arboriculture, which involve outdoors work, might appeal to inmates. The County Agent then contacted specialists in forestry and arboriculture to design a cur- riculum. Initially, Extension specialists designed a draft curriculum and learning objectives reviewed by the County Agent, Warden, and Prison Education Officer who suggested revisions based on the unique context and needs of the audience. Each curriculum topic was delivered during one weekly period lasting one to two hours. The following topics were addressed during the course: (1) forest management planning, (2) site preparation, (3) planting pine trees, (4) natural regeneration, (5) harvesting and best management practices, (6) financial considerations, (7) timber marketing, (8) pine plantation thinning, (9) prescribed burning, (10) taxation, (11) logger safety, (12) wildlife habitat, and (13) arboriculture.

Instructors were required to follow standard security protocol and advised to treat inmates with respect, but to avoid over sociability as inmates are adept at manipulating associations. The Warden required inmates to be on their best behavior in exchange for the privilege of participating in the educational program. Participants who broke this rule were expelled from the course. Each class was video-taped for later viewing by state correctional facilities.

Three modes of evaluation were employed. The Institutional Review Board determined the evaluation process assessing the effectiveness of educational outreach in a correctional facility did not qualify as human subjects research (45 CFR 46.102[f]) and therefore did not require IRB oversight. Inmate participants were verbally evaluated on the prior week's class before starting each class. Weekly written evaluations were not distributed because, as the Warden explained, such an approach could contribute to instability in the classroom if prisoners viewed it as overly formal. It is important to remember that some students may have been reticent to complete formal evaluation due to previously negative classroom experiences marked by feelings of failure. Instead the County Agent, who was familiar with each topic, would ask a set of five to ten multiple choice knowledge questions to which inmates would respond by raising their hands. The County Agent tallied responses and participant names were not recorded.

At the end of the course, an anonymous written evaluation was administered to 16 students. On a five-point scale from very poor to excellent, the evaluation measured program assessment, including self-reported usefulness of information, quality of instruction and materials, and perceived change in knowledge. Additional questions addressed perceived likelihood of working in forestry in the future, need for more educational classes, likelihood of attending educational classes, and an open-ended question asking for course suggestions. We opted for a limited number of questions to mitigate the burden placed on participants. Self-reported results on the final course evaluation must be interpreted with caution since inmates may be influenced by their perceptions of responses acceptable to facility managers who were present during classroom evaluation and who were provided an evaluation report compiled by the County Agent.

A third set of evaluation data was collected through interviews with the curriculum committee. Interviews are a common and expeditious method of program assessment, particularly among key participants (Luloff 1999). Ten individuals involved with the project, including eight instructors and two prison staff, were interviewed. A questionnaire guided the interviews through a series of open-ended questions. The 
authors conducted the interviews generally lasting between fifteen and twenty minutes. Interview questions included: (1) Did you think your lecture was successful? (2) How did the subjects react to the information you provided? (3) Were there any problems? (4) Is there anything you would do differently in the future? and, (5) Is there value in providing this type of program? This article reports results from the latter two evaluation methods using the interview questions as a guiding framework.

\section{Results}

\section{Did you think your lecture was successful?}

Overall, project personnel believed lectures accomplished the learning objectives. Facility managers (the warden and education officer) were thrilled with the program and requested future courses, and were satisfied with the outcome of the program. Several instructors noted students were exemplary and, in some ways, were more attentive and appreciative than traditional audiences. One instructor said:

"Yes [my lecture was successful], especially my first one. The inmates asked lots of questions and appeared interested and engaged. They thanked me profusely for giving them the books as reference."

However, this instructor also suggested students appeared fatigued during his second presentation, the last of the course.

Similarly, the final course evaluation results suggested high student satisfaction with the course. Sixteen (100\%) students rated the quality of the speakers as very good to excellent. Students also tended to rate the material highly, with 13 reporting very good to excellent. As well, students reported a substantial change in knowledge. An instructor of wildlife management and recreation noted some prior knowledge when he provided a lecture; however, only one student reported very good knowledge of the topics in general prior to the course. At the course's conclusion, six of seven respondents said they had very good to excellent knowledge. What is important here is not actual knowledge gained, which was not measured, but students' perception of change because this relates to self-esteem and transformative process (Mezirow 2000).

\section{How did the subjects react to the information you provided?}

Project personnel, including facility managers, were impressed with students' enthusiasm for learning. Without exception, project personnel reported that students "...enjoyed the lectures and soaked up the information like sponges." One instructor recalled, "A couple [students] had questions on career opportunities. I mentioned outfitters as guides, or state parks as grounds keepers." A harvesting operations instructor said students related to machine operation even though they were not familiar with the specific logging equipment.

Commenting on how word of the program spread throughout the institution, facility managers reported "... there [was] a lot of interest from those that have not yet attended." Underscoring this, managers also said most students seemed to have thoroughly read the material before attending classes. This is important since there is a tendency for inmates to have possessed few educational inclinations prior to their prison experience (Harlow 2003).

\section{Were there any problems? If so, what?}

Project personnel did not describe any major problems. Facility mangers did not report problems and were pleased the program was completed without serious issues. Other than instructors' initial reluctance at the idea of prison programming, lecturers said "Attendees were conscientious of my time and well-behaved." The only major weakness mentionednot an operational problem-was concern that the program would not result in actual post-incarceration behavior change. The instructors, who normally work with the general public, base their programs on influencing knowledge and behavior change in contrast to the less tangible objectives of this project. For their part, eight of 16 students reported excellent chances of working in the forestry/tree care industries in the future, while two of 16 reported such employment unlikely. Six of 16 said their chances were neither good nor poor.

\section{Is there anything you would do differently in the future? If so, what?}

In response to this question, facility managers suggested additional classes and readings. Facility managers clearly believed the program was appropriate for the audience in terms of time and difficulty. Like the instructors, they would have preferred hands-on demonstrations, but recognized this would be "difficult due to inmate supervision requirements." In response to this challenge, one instructor had the idea of utilizing videos of machine operation, which he thought would get students' attention. Another suggested having a field day while another advocated a work-release program to give students a "vision of how to do things on the ground." Demonstrations may be limited to those students facility managers believe are deserving of such activities.

\section{Is there value in providing this type of program?}

Project personnel expressed mixed responses to this question. Again, responses may be influenced by comfort level with a non-traditional audience, delivery strategy, and project objectives. One instructor noted the difficulty of bearing in mind that the program was not only to increase knowledge and awareness of potential employment opportunities, but also to enlighten inmates and moderate a tense environment. Thus, when one instructor said the value is "limited and not the optimal impact", he could have overlooked the less tangible benefits of prison education. It is important to note that the instructors who were most reticent to participate in the project were also most likely to perceive limited value in the project. These results underscore the importance of having full buy-in from instructors, which also improves instructional quality.

Another instructor indicated that, while forest management per se may have limited practical value since it requires a two-year degree and many employers may be hesitant to hire ex-inmates, logging may be a more appropriate option. This instructor suggested more emphasis on logging, chainsaw safety, and best management practices in future programs. A harvesting operations instructor disagreed. Although he thought the project was valuable, he noted significant barriers due to real and perceived liabilities associated with hiring ex-convicts. He thought a work-release program with support from the State and insurance companies 
would have the best chance at helping ex-inmates succeed in the logging industry.

Another instructor stated arboriculture was well-suited for ex-inmates and the State did not prohibit them from becoming tree surgeons and landscaping professionals. In addition, an instructor believed there was value in making inmates aware of the Extension program as a post-prison resource. After all, Extension provides knowledge and skills in a number of subjects besides forestry. This instructor also noted the training could be beneficial in ex-inmates' future outdoor recreation activities. Finally, one facility manager noted "some of the inmates [planned] on using this information to manage family land and [obtain] employment upon release."

Three questions on the final evaluation addressed the extent to which students valued the program. Only eight of 16 students rated their chances of working in forestry as very good or excellent, while three responded with poor to very poor. Still, 15 students said they wanted more forestry classes with one student noting "[We are] very needful for more classes!" and another student commenting, "What I like: [the course] gave me more knowledge of how important trees are." A third student wrote, "I enjoyed everything about this class. It was one of the best I've been to... The best thing was multiple speakers giving us greater diversity." Although many students appreciated the program, several were critical of the lecture format and would have benefitted more from hands-on activities.

Finally, 15 students stated the chances of attending other educational sessions were very good to excellent. Suggestions for education topics included business management, basic computer skills, hair styling, small engine repair, basic college courses, culinary, bee farming, and many others. Outdoor recreation, including guiding and game management were common suggestions for future programs. These results suggest this group of inmates desired to learn and had potential for transformative behavioral change.

\section{Conclusion}

Referring to a Rikers Island Prison Complex horticulture program, James Jiler (2009: 185) acknowledged that, "On its own, [the program] is not a panacea for the huge challenges facing the criminal justice system either in New York City, the state, or country." However, given the costs of prison-based punishment and reform, the existing concept of the correctional facility must be reconfigured as a benefit to society instead of a resource sink. Our experience teaching forestry and arboriculture in a Mississippi correctional facility suggests Cooperative Extension is ideally positioned to address this challenge.

Forestry and arboriculture are educational options inmates across the nation may find interesting and relevant as potential post-release employment. A lack of hands-on experience was a limitation of this program; however, future opportunities may include activities such as establishing a nursery, tree establishment and pruning, and work-release. Undoubtedly, tree care, nursery management, and outdoor recreation are natural resource training topics that may be best suited for inmates with limited education and which would increase their employability. Such topics serve as opportunities for Extension professionals interested in providing correctional facility education. Regardless, this pilot program suggests that natural resources programming is relevant and valuable. The Department of Corrections agrees, and has requested programming to facilities across the state. Continuation of this program would benefit from measuring long-term impact on participating inmates following release, possibly through the parole system.

\section{References}

Bureau of Justice Statistics. 2015. Annual probation survey, annual parole survey, annual survey of jails, census of jail inmates, and national prisoner statistics program, 1980-2014. [online] Available from: www.bjs.gov/index.cfm?ty=tp\&tid=1 [accessed on 16 June 2016].

Coley, R. and P. Barton. 2006. Locked up and locked out: An educational perspective on the U.S. prison population. Educational Testing Service. Available from: https://www.ets.org/Media/Research /pdf/PIC-LOCKEDUP.pdf [accessed on 16 June 2016].

Davis, L.M., R. Bozick, J.L. Steele, J. Saunders, J.N.V. Miles. 2013. Evaluating the effectiveness of correctional education: A metaanalysis of programs that provide education to incarcerated adults. RAND Corp., Washington, D.C.

Ewert, S. and T. Wildhagen. 2011. Educational characteristics of prisoners: Data from the ACS. Presented at the Annual Meeting of the Population Association of America, Washington, DC, March 31April 2, 2011. SEHSD Working Paper \# 2011-8. U.S. Census Bureau Housing and Household Economic Statistics Division. Available from: http://www.census.gov/library/working-papers/2011/demo/ SEHSD-WP2011-08.html [accessed 16 June 2016].

Harlow, C. 2003. Education and correctional populations. U.S. Department of Justice, Bureau of Justice Statistics. Available from: www.bjs.gov/content/pub/pdf/ecp.pdf [accessed 16 June 2016].

Jiler, J. 2009. Restoring lives, transforming landscapes: The greenhouse program at Rikers Island jail. In L. Campbell and A. Wiesen (eds.). Restorative Commons: Creating Health and Well-being Through Urban Landscapes. pp. 179-187. Gen. Tech. Rep. NRS-P39. Newtown Square, PA. U.S. Dept. Agric. Forest Service, Northern Research Station. 278 p.

Kyckelhahn, T. 2011. Justice Expenditures and Employment, FY 1982-2007 - Statistical Tables (NCJ 236218). U.S. Department of Justice, Bureau of Justice Statistics. Available from: bjs.gov/content/ pub/pdf/jee8207st.pdf [accessed 16 June 2016].

Luloff, A.E. 1999. The doing of rural community development research. Rural Soc. 9(1): 313-327. doi:10.5172/rsj.9.1.313.

Mezirow, J. (ed.) 2000. Learning as transformation: Critical perspectives on a theory in progress. Jossey-Bass, San Francisco.

Reld, D. and S. Dorn. 1995. Horticulture: Meeting the needs of special populations. HortTech. 5(2): 84-103. Available from: horttech.ashspublications.org/content/5/2/94.full.pdf [accessed 16 June 2016].

Robinson, M.L. and A.M. O'Callaghan. 2008. Expanding horticultural training into the prison population. J. Extension 46(4):4IAW4. Available from: www.joe.org/joe/2008august/iw4.php [accessed 16 June 2016].

World Prison Brief. 2016. [online] Available from http://www.prisonstudies.org/ [accessed on 16 June 2016]. 